Marta Kamińska (iD) https://orcid.org/0000-0001-7553-9826

Uniwersytet Jagielloński

Katarzyna Ornacka (D) https://orcid.org/0000-0002-9305-8476

Uniwersytet Jagielloński

Dominika Beszłej

Placówka Wsparcia Dziennego „Świetlica św. Kingi” w Wieliczce

\title{
STREETWORKER W KONTAKCIE Z DZIECKIEM - WARUNKI I NARZĘDZIA PRACY - KILKA UWAG TEORETYCZNO-PRAKTYCZNYCH
}

\begin{abstract}
Streetworker in relation with a child - working conditions and tools - some theoretical and practical remarks

Young people are the most vulnerable group because of their sensitivity and vulnerability to injury. Children have great potential for development and are able to succeed in their future lives, both private and professional, if they have the opportunity to grow up in the right environment and follow a good example. Although the work of a streetworker is non-institutional, like any profession or group, streetworkers are guided by a set of guidelines, norms and rules regarding their behaviour, attitudes, getting in contact with the child and their family, relationships with other streetworkers, etc. They also use a set of tools that serve them to work effectively on the street. These elements play a fundamental role in working with young people. In this paper we will highlight the most important of them. They may become a source of reflection for future streetworkers.
\end{abstract}

Key words: streetwork, children, streetworker's working principles and values

Młodzi są grupą najbardziej narażoną na różnego rodzaju niebezpieczeństwa ze względu na wrażliwość i podatność na zranienie. Dzieci mają ogromny potencjał rozwoju i są one w stanie osiągnąć sukces w przyszłym życiu zarówno prywatnym, jaki zawodowym, jeśli tylko mają możliwość dorastania w odpowiednim środowisku oraz naśladowania dobrego przykładu. Dzieci ze swej natury są zależne od osób dorosłych, polegają na 
nich, by ci zapewnili im odpowiednie warunki do godnego życia. Przez swoją naturalną ufność są podatne na manipulację, dlatego tak łatwo o degradację emocjonalną i psychofizyczną dziecka. Bardzo często zdarza się, że dzieci ranione są przez osoby dorosłe, które same w swoim dzieciństwie ulegały różnego rodzaju niszczącym zaniedbaniom. By przerwać ten ciąg, należy dawać dzieciom wsparcie, uczyć je asertywności i pokazywać im możliwości rozwoju. Równolegle należy pomagać rodzinom, które borykają się z problemami mogącymi powodować pojawianie się nadużyć w stosunku do dzieci.

Mimo tego, że praca streetworkera ma charakter nieinstytucjonalny, to tak jak w każdym zawodzie czy grupie zawodowej streetworkerzy kierują się zestawem wskazówek, norm i zasad dotyczących ich zachowania, postaw, wchodzenia w kontakt $\mathrm{z}$ dzieckiem oraz jego rodziną, relacji z innymi streetworkerami itd. Korzystają również z zestawu narzędzi, który służy im do efektywnej pracy na ulicy. Elementy te odgrywają fundamentalną rolę w pracy z młodymi osobami.

\section{Jaki powinien być streetworker?}

Streetworker powinien przede wszystkim darzyć miłością drugiego człowieka ze wszystkimi wynikającymi z tego konsekwencjami, czyli pełnym poszanowaniem osoby, jej godności i sytuacji, w której obecnie się znajduje. Streetworker musi mieć pełną świadomość swojej tożsamości (Stowarzyszenie „PoMoc” dla Kobiet i Dzieci im. Marii Niepokalanej 2010: 18) i własnych trudnych sytuacji, które przeszedł w przeszłości. Sytuacje, które są w życiu osoby świadczącej pomoc nieprzepracowane i nierozwiązane do końca, „środowisko ulicy” może wyczuć w kontakcie ze streetworkerem i wykorzystać przeciwko niemu. Dzieci i młodzież szczególnie są w stanie dostrzec „czułe miejsca” osoby pomagającej i mocno w nie uderzyć.

Ważnym elementem są cechy charakteru, bez których trudno mówić o efektywnej pracy streetworkerskiej. Należą do nich między innymi: odwaga, cierpliwość, pogoda ducha, pewność siebie, otwartość, dyskrecja, opanowanie, empatia, odporność itd. Streetworker powinien posiadać dobrze rozwinięte umiejętności komunikacji werbalnej i niewerbalnej potrzebne do prowadzenia w sposób profesjonalny rozmowy z osobą potrzebującą (StreetInvest 2013). Motywacja, jaką kieruje się streetworker w swojej pracy, ma również niemałe znaczenie. Wiele razy można spotkać osoby w zawodach skierowanych na drugiego człowieka, które zdecydowały się na pomaganie po doświadczeniu kryzysu lub innych trudności w swoim życiu. Niestety, część takich osób swoją pracę i świadczoną pomoc często nieświadomie motywuje potrzebą dowartościowania siebie samego, a nie chęcią pomocy innym. W pracy z dziećmi, w ich środowisku należy pamiętać, że to one są odbiorcami działań terapeutycznych. Streetworker nie może pozwolić sobie na poszukiwanie w „środowisku ulicy” pocieszenia. Może bowiem dojść do sytuacji, w której nie otrzymawszy oczekiwanego wsparcia, znajdzie osobę, która stanie się obiektem jego frustracji. 


\section{Jakie są sposoby pracy na ulicy?}

Aktywny i pasywny (Stowarzyszenie „PoMoc” dla Kobiet i Dzieci im. Marii Niepokalanej 2010: 22), które doskonale się uzupełniają. Sposób aktywny to bezpośredni kontakt z dziećmi, rozmowa, organizowanie czasu czy po prostu obecność. Sposób pasywny to początkowa obserwacja miejsca, w którym młodzi ludzie spędzają swój czas. Dzięki obserwacji streetworker daje się poznać i zaznacza swoją obecność w środowisku, po czym może nastąpić faza aktywna, czyli wejście w bezpośredni kontakt z dziećmi i młodzieżą.

\section{Jakie są etapy pracy na ulicy?}

Pierwszy etap to badanie środowiska, w które streetworker chce wejść. Badanie to ma dwojakie znaczenie. Należy poznać „teorię miejsca”, czyli osadzenie go w dzielnicy i miejscowości, uwarunkowanie społeczne i kulturowe, zdobyć wiedzę na temat mieszkańców, ich statusu, zamożności, występujących w okolicy mniejszości etnicznych lub religijnych itp. Duże znaczenie ma charakter praktyczny, a więc poznanie osób z danej okolicy (Réseau International des Travailleurs Sociaux de Rue 2008: 23). Drugi etap to obecność. Chcąc wejść w środowisko i nawiązać relację z młodymi ludźmi przebywającymi na danym terenie, należy zaznaczyć w nim swoją obecność, przebywając tam i początkowo nie nawiązując z nikim kontaktu. Należy robić to regularnie, by móc poznać specyfikę miejsca $\mathrm{z}$ innej perspektywy niż w pierwszym etapie i zaobserwować osoby, które odwiedzają to miejsce. Po pewnym czasie streetworkerzy stają się naturalnym elementem danego terenu, już nie są "obcy” i bywa, że dzieci i młodzi ludzie sami nawiązują z nimi kontakt (Stowarzyszenie „PoMoc” dla Kobiet i Dzieci im. Marii Niepokalanej 2010: 24). Trzeci etap polega na przedstawieniu się i podaniu przyczyny obecności w danym terenie. Czwartym etapem jest budowanie więzi z grupą przez systematyczne odwiedziny miejsca i oferowanie swojej pomocy. Jeśli chodzi o pracę z dziećmi, to bardzo ważne jest dla nich, by streetworker był szczery, punktualny i wyrozumiały, a także umiejący przyznać się do błędu. Są to cechy budujące trwałą relację, które nie są łatwe do wypracowania w świecie, w którym powszechne są „białe kłamstwa”, brak szczerości i stawiania siebie w prawdzie. Warto jednak, by streetworker podjął trud mówienia prawdy, ponieważ w kontakcie z dzieckiem, które samo ucieka się bardzo często do oszustw, może on stać się motywacją do szczerości i do dalszego rozwoju. Piąty etap, ostatni i najdłuższy, to wsparcie i interwencja, czyli stała obecność i pomoc.

\section{Jakich błędów nie należy popełniać w pracy na ulicy?}

Pracując w obszarach objętych ubóstwem i wieloma problemami społecznymi, streetworker jest permanentnie obciążony emocjonalnie i psychicznie. Bez superwizji i ciągłej pracy nad sobą nie jest on w stanie udźwignąć ciężaru, jakim jest przygniatany. Szczególnym 
obciążeniem cechuje się praca z młodymi ludźmi. Streetworkerzy sami często mają dzieci, poza tym są ludźmi wrażliwymi, dlatego sytuacja młodych osób, którym na co dzień pomagają, może dotykać ich w wyjątkowy sposób. Mimo wytycznych pracy streetworkera zdarzają się sytuacje, które przez silny nacisk emocjonalny doprowadzają do nadużyć ze strony streetworkerów. Korzystając z doświadczenia zgromadzonego przez Stowarzyszenie „PoMoc” pracujące z kobietami i dziećmi, można wymienić następujące błędy streetworkerów:

- "każdy kontakt musi się udać” - to częsty błąd osób, które chcą perfekcyjnych kontaktów z osobami potrzebującymi. Należy jednak pamiętać o dobrowolności i o tym, że dzieci nie zawsze chcą rozmawiać, czasem zdarza się agresja słowna lub nawet fizyczna z ich strony. Najczęściej sytuacje te wynikają nie z winy streetworkera, ale z powodów zewnętrznych, takich jak na przyykład problemy w relacjach rodzinnych;

- postawa zbyt bierna lub zbyt aktywna - obie te postawy przeszkadzają w utrzymaniu prawidłowej relacji z dzieckiem. Zbytnie wycofanie w kontakcie daje ogląd całości sytuacji, ale sprawia, że relacja z dzieckiem staje się coraz mniej znacząca dla obu stron. Postawa zbyt aktywna może prowadzić do zniechęcenia ze strony dziecka lub do przekroczenia właściwych relacji i stosunków;

- nienaturalność - błąd ten często jest popełniany przez osoby pracujące w sektorze pomocowym. To idealizowanie swoich postaw, reakcji, zachowań oraz obawa o popełnienie błędu. Dzieci są bardzo czujne i są w stanie wyczuć, czy ktoś udaje jakieś zachowanie, dlatego nienaturalne zachowanie streetworkera może go oddalić od dziecka. Może również sprawić, że dziecko, widząc wyidealizowane zachowanie streetworkera, poczuje się gorsze z powodu braku umiejętności naśladowania takiej postawy;

- brak elastyczności - to próba podporządkowania sobie osób, którym się pomaga. Należy pamiętać, szczególnie w pracy z osobami żyjącymi w innych warunkach, środowisku oraz z osobami w innym wieku, że potrzebne jest dostosowanie się do przestrzeni, grupy i cech charakteru. Nie można oczywiście wniknąć w grupę i stać się jej częścią, ale należy być w stanie odpowiadać na potrzeby, zachowując swoją integralność;

- zatarcie właściwych granic relacji w pracy - to kolejny popularny problem osób pomagających zawodowo. Zdarza się, że pracując z daną grupą czy osobą dłuższy czas, mając o sobie coraz więcej informacji, doprowadza się do wytworzenia więzi emocjonalnej i powolnego zatarcia się granicy „pomagacz” - osoba potrzebująca i przejścia w relację przyjacielską. Streetworkerzy pracujący z dziećmi są narażeni w sposób szczególny na zatarcie granic w relacji, ponieważ dzieci często wypytują o życie prywatne, o adres czy numer telefonu. Dzieci mogą również przywiązać się do jednego streetworkera i bez odpowiedniej reakcji odrzucać próby nawiązywania relacji ze strony innych streetworkerów. Należy więc być czujnym, aby móc w porę zareagować i nie doprowadzić do zatarcia tych granic;

- „no, w końcu byś coś zmienił!” - to postawa tak zwanego nauczyciela lub rodzica. Wynika ona z niecierpliwości i braku wytrwałości. To pokazywanie frustracji 
wynikającej z niezmieniającej się sytuacji osoby, której udziela się pomocy. Należy jednak pamiętać, jak wrażliwa może być to osoba, i wystrzegać się takiego podejścia, które może zniechęcić do dalszego kontaktu (Stowarzyszenie „PoMoc” dla Kobiet i Dzieci im. Marii Niepokalanej 2010: 26-29).

Zestaw ten powinien dać ogólny obraz, jakich postaw i zachowań należy się wystrzegać, by relacja z dzieckiem rozwijała się prawidłowo.

\section{Co nie jest zadaniem streetworkera?}

Korzystając po raz kolejny z dorobku streetworkerów z katowickiego Stowarzyszenia „PoMoc”, można wskazać na nieodpowiednie zadania i role, w jakie wchodzą streetworkerzy w pracy z dziećmi (Stowarzyszenie „PoMoc” dla Kobiet i Dzieci im. Marii Niepokalanej 2010: 30-31). Po pierwsze, streetworker nie jest instytucją nadzorującą, a jego zadaniem jest towarzyszenie, a nie kontrolowanie i egzekwowanie właściwych zachowań. Po drugie, chęć zmiany powinna wychodzić od osoby, której się pomaga, streetworker powinien więc raczej czekać na inicjatywę dziecka i na prośbę o pomoc. Po trzecie, streetworker nie może pozwolić sobie na ocenę zachowań dziecka i nie jest jego zadaniem osądzanie wyborów, szczególnie tych, które umotywowane są negatywnym doświadczeniem dziecka. Po czwarte, streetworker nie jest rodzicem dziecka, z którym pracuje, nie może więc odpowiadać za każde jego nieodpowiednie zachowanie na przykład w miejscach publicznych, a tym bardziej w przestrzeni codziennego przebywania dziecka, ani obwiniać się o nie. Dziecko, ponosząc konsekwencje swojego nieodpowiedniego zachowania, samo jest w stanie wyciągnąć wnioski na przyszłość.

Świadomość zakresu zadań, które podejmują streetworkerzy w kontakcie z dzieckiem, pozwala uniknąć zranienia dziecka i skupić się na procesie jego poznania. Dodatkowo, standaryzacja pracy pomaga profesjonalistom zminimalizować skutki trudnych doświadczeń, z jakimi zgłaszają się dzieci. Do pracy streetworkerskiej można wykorzystywać narzędzia, dostosowując je odpowiednio do grup, z którymi wchodzi się w kontakt. Najważniejszym narzędziem w pracy streetworkera jest on sam, jednak inne elementy, które zostaną wymienione poniżej, mogą znacznie przyczynić się do polepszenia jakości pracy streetworkera. W pracy ulicznej z dziećmi i młodzieżą można wykorzystać wiele narzędzi mogących uczynić działania streetworkerskie bardziej efektywnymi. Są to między innymi: przedmioty - gry edukacyjne, przedmioty do zorganizowania czasu na podwórku i w przestrzeni miejskiej; język i ubiór - powinny być w pewnym stopniu dostosowane do środowiska, w jakim pracujemy, język streetworkera powinien być zrozumiały dla każdego i dopasowany do rozmówcy, nie należy używać wulgaryzmów, a ubiór nie powinien dać odczuć dziecku różnicy w statusie materialnym; pierwsza pomoc - podstawy z udzielenia pierwszej pomocy mogą przydać się w życiu każdego człowieka, także w pracy streetworkera (Stowarzyszenie „PoMoc” dla Kobiet i Dzieci im. Marii Niepokalanej 2010: 38). 
Jak można zauważyć, warsztat wskazówek i narzędzi, a także norm i zasad pracy streetworkera jest rozbudowany. Każdy streetworker jest indywidualnie ukształtowany i posiada wyjątkowe cechy charakteru, przychodzi z innym doświadczeniem, dlatego narzędzia te cały czas rozbudowują się, pozwalając doskonalić pełnione przez streetworkerów funkcje. Należy zawsze pamiętać, że w pracy streetworkera z dziećmi i młodzieżą żadne narzędzia nie są w stanie zastąpić dziecku wyjątkowego i indywidualnego kontaktu ze streetworkerem. Dlatego właśnie bardzo ważne jest, by organizacje zatrudniające streetworkerów dbały o ich rozwój oraz zapewniały stałą superwizję i możliwość przepracowywania trudnych sytuacji i przypadków. Troszczenie się o rozwój i higienę psychiczną pracownika jest bowiem jednym z kluczy do osiągnięcia pozytywnych rezultatów w pracy z młodym człowiekiem.

\section{Postawy i zachowania, jakie przyjmuje streetworker w pracy z dziećmi i młodzieżą}

Streetworker w pracy z dziećmi i młodzieżą ma na względzie przede wszystkim ich dobro i rozwój. Aby dziecko mogło rozwijać się prawidłowo, musi mieć zapewnione do tego odpowiednie warunki. Nie każda rodzina jest w stanie dać dziecku poczucie bezpieczeństwa, relację bliskości, dobry przykład, wsparcie czy choćby zwyczajną obecność. W tym miejscu rodzina powinna otrzymać odpowiednie wsparcie, by relacje w niej obecne mogły zostać usprawnione. Działania te jednak nie zawsze są wystarczające lub nie zawsze przynoszą odpowiednie skutki. Przyjmując, że każda osoba wymaga indywidualnego podejścia oraz że są potrzeby, których brak powiela się wśród wielu młodych ludzi, streetworker może wypracować sobie pewien uniwersalny zestaw narzędzi i zachowań. Zestawy te natomiast mogą tworzyć postawy, którymi kierować się będą pracownicy outreach w pracy z młodymi osobami. Potrzebą niezaspokojoną wśród dzieci pochodzących ze środowisk zmarginalizowanych jest na przykład obecność odpowiedzialnego dorosłego, który nie manipuluje dzieckiem oraz nie ocenia go. W takim wypadku streetworker może przyjąć postawę „kompana” i stosując odpowiedni zestaw cech, może pomóc dziecku wypełnić taki brak. Przyjmowanie postaw w pracy z dziećmi i młodzieżą nie może być czymś w rodzaju teatru, ale musi być naturalnym zachowaniem, dlatego streetworker może przyjąć tylko taką postawę, w jakiej czuje się dobrze i do której posiada odpowiednie cechy osobowości.

W środowiskach zmarginalizowanych szczególnie często występują różnego rodzaju uprzedzenia do służb społecznych, mundurowych (policji, straży miejskiej) czy oświatowych. Uprzedzenia te powodują, że osoby przyjmujące zachowania kojarzone z którąś z tych grup mogą zostać odepchnięte. Dlatego postawa streetworkera przybierającego postawę upominającą i przynaglającą do poprawy zachowania może być kojarzona z postacią policjanta, a przez to grupa może zniechęcić się do pracy ze streetworkerem.

Streetworkerzy są osobami o różnym przygotowaniu zawodowym i osobistym. Niesiony przez nich bagaż doświadczeń może definiować w pewien sposób, które postawy 
przyjmą. Zdarza się, że decyzja o pracy z dziećmi i młodzieżą metodą outreach jest podejmowana ze względu na podobne doświadczenia - wyjście ze środowiska zmarginalizowanego lub trudne doświadczenia w relacjach rodzinnych. Jeżeli te trudności są przez streetworkera przepracowane, to staje się on cennym źródłem rozwiązywania problemów. Jeśli jednak streetworker nie zdążył do końca wyjść z trudnych sytuacji, będzie to mocno rzutowało na pracę z młodymi ludźmi. Istnieje także większe prawdopodobieństwo wchodzenia przez takiego pracownika w nieodpowiednie role, na przykład przyjaciela. Należy jeszcze raz zatem podkreślić, że aby przyjąć odpowiednie postawy w pracy z osobami młodymi, powinno się stawiać na pierwszym miejscu zdolność do dawania im odczucia samostanowienia ${ }^{1}$ oraz szacunek wobec ich wyborów.

Streetworker w pracy może przyjmować postawy, które wpływają na relację z dzieckiem w sposób pozytywny lub negatywny. Postawy wpływające pozytywnie na relację powinny skutkować polepszeniem jakości kontaktu z dzieckiem i ich wspólnym rozwojem oraz satysfakcją streetworkera $\mathrm{z}$ wykonywanej pracy. Te drugie zaś, z racji ich ograniczającego i narzucającego charakteru, sprawiają, że relacja z dzieckiem od spotkania do spotkania pogarsza się lub zostaje przerwana.

Poniżej przedstawionych zostanie pięć przykładów postaw pozytywnie wpływających na relacje. Wszystkie te postawy cechują się zasadami dbałości o szacunek, wolność, rozwój oraz stawianie na samodzielne podejmowanie decyzji przez dziecko. Pracownik przybierający pozytywne postawy jest akceptowany, szanowany i lubiany w grupie, w której pracuje. Akceptacja, jaką obdarzony może być streetworker przez dziecko lub całą grupę, jest otwartą drogą do procesu towarzyszenia i zmiany. Zdobycie akceptacji od osób często bardzo nieufnych nie jest łatwym zadaniem dla streetworkera. Musi on wykazać się cierpliwością, dlatego że młode osoby mogą chcieć testować jego granice i wytrzymałość. Dobrze przygotowany streetworker potrafi jednak użyć swoich umiejętności i doświadczenia w taki sposób, że młodzi ludzie zaczynają od akceptacji jego osoby, a kończą na czerpaniu od niego inspiracji.

\section{Dobry przykład}

Jest to jedna z najważniejszych postaw, jakie może przybrać streetworker. Głównym narzędziem pracy z młodym człowiekiem nie są tutaj upomnienia, nakazy i zakazy. Streetworker nie wytwarza niezdrowej relacji, ale akceptuje w pełni wybory młodego człowieka i rozumie je. Dzięki akceptacji czynników mogących negatywnie wpłynąć na kontakt z dzieckiem, streetworker buduje relację w odpowiedni sposób. Głównym narzędziem pracy staje się w tym przypadku przede wszystkim postawa streetworkera, jego własne wybory, jego cechy charakteru oraz doświadczenie. Dziecko może

1 Prawo dziecka do samostanowienia jako prawo do samodzielnego podejmowania własnych decyzji, dokonywania wyborów związanych z codziennością w pełnej wolności oraz ponoszenia wszystkich konsekwencji wynikających z tychże wyborów. 
zaczerpnąć w przyszłości z przykładu streetworkera, widząc, jaką postawę przybiera on wobec różnych ważnych dla niego kwestii, nie zmuszając go przy tym do czynienia w ten sam sposób. Bardzo ważnym, a trudnym do wykształcenia u młodych osób elementem osobowości jest asertywność i zdolność do dokonywania własnych wyborów. Streetworker swoim przykładem może pokazać, że dokonywanie wyborów w odważny sposób może znacząco przyczynić się do zwiększenia poczucia własnej wartości, jakości postrzegania przez innych oraz poczucia samostanowienia. Streetworker w kontakcie $\mathrm{z}$ dzieckiem nie może udawać, ale powinien być $\mathrm{w}$ pełni naturalny $\mathrm{w}$ tym, co robi i jakich wyborów dokonuje. Jeśli ma on niskie poczucie własnej wartości i nie radzi sobie ze swoją sferą emocjonalną, wtedy nie jest w stanie dawać dobrego i godnego naśladowania przykładu.

\section{Kompan}

Streetworker, który jest kompanem dziecka, przede wszystkim nie krytykuje, rozumie, dlaczego dziecko dokonuje danych wyborów, i nawet jeśli są to wybory w jego ocenie niewłaściwe, nie przeszkadza mu to w towarzyszeniu dziecku. W tej postawie chodzi przede wszystkim o obecność. Dzieci, które pochodzą z rodzin zmarginalizowanych, doświadczają sytuacji, w których po popełnieniu jakiegoś błędu osoby ważne dla nich odwracają się od nich. Zdarza się także, że gdy dziecko popełni jakiś czyn społecznie nieakceptowany, zostaje ono odrzucone. W środowiskach wykluczonych często dochodzi do łamania prawa nie tylko przez dorosłych, ale także przez młodzież i dzieci. Rolą streetworkera nie jest jednak egzekwowanie kar i wchodzenie w kompetencje osób za to odpowiedzialnych, lecz towarzyszenie. Postawa ta jest w pewien sposób przeciwieństwem wchodzenia w rolę „policjanta”.

\section{Wzmacniający poczucie własnej wartości}

Poczucie własnej wartości jest elementem osobowości, który podpowiada dziecku, co ono samo myśli o sobie i jak bardzo wartościowe jest we własnych oczach (Young, Hoffmann 2004: 87). Odpowiednio wysokie poczucie własnej wartości jest czynnikiem niezbędnym do prawidłowego rozwoju dziecka, do rozwoju jego umiejętności, do budowania relacji z rówieśnikami i innymi osobami z najbliższego otoczenia. Pozwala mu ono również nie skupiać się na tym, co inni o nim myślą. Poczucie własnej wartości jest kształtowane u dziecka przede wszystkim przez rodziców. To oni przez odpowiednią informację zwrotną dają dziecku sygnały, że jest ono dla nich ważne i wartościowe. W rodzinach wykluczonych, w których czasem podstawowe potrzeby nie są do końca zaspokojone, rodzice mogą nie zwracać uwagi na poczucie własnej wartości dziecka i przez to może mieć ono problem z obrazem samego siebie (Griffin 1994: 124-128). Praca streetworkera w celu wypracowania wyższego poczucia własnej wartości dziecka 
może być trudna z dwóch powodów. Po pierwsze dlatego, że rodziny, które borykają się z różnego rodzaju uzależnieniami, przemocą, biedą itd., przykładają mniejszą uwagę do budowania poczucia własnej wartości dziecka. Trzeba zatem pomagać im w uświadomieniu istotności wzmacniania dziecka, zadanie to jednak nie zawsze należy do streetworkera, ale często do innych osób pracujących z rodziną. Drugą trudnością jest to, że wzmacnianie poczucia własnej wartości u dziecka jest procesem, nad którym należy pracować codziennie. Streetworker nie jest opiekunem dziecka i nie spędza z nim większości dnia w przeciwieństwie do jego rodziny. To, co wypracuje streetworker z dzieckiem, może być zakłócane przez codzienne negatywne doświadczenia w rodzinie. Mimo to dla rozwoju dziecka wzmacnianie jego poczucia własnej wartości jest bardzo ważne, a streetworker całokształtem swojej pracy może znacznie przyczynić się do rozwoju tego pola osobowości dziecka.

\section{Źródło informacji zwrotnej}

Informacja zwrotna jest ściśle związana z poczuciem własnej wartości. Pozytywna informacja zwrotna udzielona dziecku w prawidłowy sposób może wzmocnić poczucie własnej wartości oraz motywację do dalszego działania. Negatywna informacja zwrotna może obniżyć poczucie własnej wartości i zmniejszyć chęci i motywacje do działania. Od informacji zwrotnej zależy, jak dziecko będzie siebie postrzegało. Jeśli dziecko po otrzymaniu złej oceny w szkole lub innego rodzaju niepowodzeniu będzie dostawało od rodzica komunikat: „Jak zawsze! Do niczego się nie nadajesz, zejdź mi z oczu!”, to wpłynie to negatywnie na jego globalną samoocenę oraz na relację między nim a rodzicem. Jeśli natomiast dziecko otrzyma pozytywną informację zwrotną: „Widzę, że nie dostałeś pozytywnej oceny. Nie przejmuj się, starałeś się. Na następny raz przyłożysz się bardziej, dłużej się pouczysz i zobaczysz, na pewno się uda”, to jego poczucie własnej wartości nie obniży się, a relacja z rodzicem będzie wzmocniona. Informacja zwrotna towarzyszy nam nieustannie, tak że nie jesteśmy w stanie jej nie udzielać. Możemy jedynie nauczyć się umiejętnie ją wykorzystywać. Streetworker, mając świadomość siły, jaką posiada umiejętne udzielenie informacji zwrotnej, może wykorzystywać ją w swojej pracy z dzieckiem. Każde pochwalenie, docenienie słowne, uśmiech, otwarta postawa wobec dziecka jest informacją zwrotną mówiącą: „Akceptuję cię i jesteś dla mnie ważny”. Dzięki informacji zwrotnej streetworker może również uczyć dziecko, w jaki sposób wzmacniać swoją asertywność i samostanowienie.

\section{Źródło wiedzy i informacji}

Streetworker pracujący z dziećmi i młodzieżą powinien mieć wiedzę nie tylko z zakresu psychologii, pedagogiki, socjologii i innych dziedzin pokrewnych. Do wykonywania tej pracy potrzebna jest również wiedza praktyczna, związana z różnego rodzaju 
procesami i przestrzeniami, w których mogą znaleźć się dzieci i młodzież z obszarów zmarginalizowanych. Potrzebna jest także wiedza na temat sieci instytucji zajmujących się pracą z dziećmi i młodzieżą. Streetworker powinien być zawsze otwarty na rozwój, nowe informacje, nowe sposoby rozwiązywania problemów jego podopiecznych i na nowości mogące przyczynić się do rozwoju pasji u dzieci i młodzieży, z którymi pracuje. Streetworker kierujący się taką postawą jest źródłem nowinek dotyczących różnego rodzaju wydarzeń lokalnych, kulturalnych, społecznych i wszystkich innych, które bezpośrednio dotyczą dziecka i jego najbliższego otoczenia. Streetworker posiadający duży zasób wiedzy ogólnej i szczegółowej wynikający z jego doświadczenia zawodowego i prywatnego oraz z ciekawości świata może stać się inspiracją i źródłem wiedzy dla dzieci i młodzieży. Wiedza posiadana przez streetworkera może stać się również elementem wpływającym na polepszenie jakości relacji z nimi.

Wyżej wymienione postawy są tymi, które naszym zdaniem pracownik outreach pracujący z dzieckiem przybiera najczęściej i które są najbardziej wartościowe dla rozwoju młodego człowieka. Każda z tych postaw zawiera w sobie element wchodzący w zbiór cech określających pojęcie „autorytetu”. Praca każdego wychowawcy może być skuteczna jedynie wtedy, gdy posiada on autorytet w oczach dzieci i młodzieży, co znaczy, że jest dla nich „osobą odniesienia” (Karłyk-Ćwik 2014: 45). Pracownik outreach przybierający postawy pozytywnie wpływające na relację z dzieckiem, oparte na zasadach poszanowania drugiego człowieka, ma szansę stać się takim właśnie autorytetem godnym naśladowania oraz sprawić, że dziecko samo będzie chciało podjąć kroki ku zmianie.

Przeciwieństwem postaw i zachowań pozytywnie wpływających na relacje z dziećmi i młodzieżą są postawy „negatywne”, które powstają w wyniku kilku czynników. Po pierwsze, postawy te tworzą się, gdy osoba dorosła czuje na sobie zbyt dużą odpowiedzialność za los młodego człowieka, a co się z tym wiąże - stawia sobie zbyt duże wymagania dotyczące pracy nad sytuacją młodego człowieka, których często nie jest w stanie wypełnić za pomocą własnych sił. W wyniku tej sytuacji w osobie pomagającej może powstać wewnętrzna frustracja, co może poskutkować porzucaniem podstawowych zasad, takich jak poszanowanie wolności dziecka. Po drugie, pracownik outreach może przybierać „negatywne” postawy, gdy ma przeświadczenie, że jest w stanie wywrzeć na dziecku większy wpływ niż inne osoby, z którymi dziecko przebywa. Na dzieci mają wpływ w dzisiejszych czasach rodzice i najbliższa rodzina, rówieśnicy, nauczyciele i wychowawcy oraz dalsza rodzina. Nie należy oczywiście zapominać o silnym wpływie środków masowego przekazu, takich jak telewizja czy Internet. Streetworker jest zatem jedną z wielu jednostek, z którymi styka się na co dzień młody człowiek. Szczególnie trudną sytuacją jest ta, w której dziecko ma do czynienia z osobami o skrajnych wartościach, dążeniach i przyzwyczajeniach. Każda z poniżej wymienionych postaw i zachowań, odpowiednio zmodyfikowana, może być zastosowana w relacji z dzieckiem w pozytywny sposób, jednak zdarza się, że nigdy do tego nie dochodzi, a kontakt z dzieckiem urywa się. Często występujące, naszym zdaniem, postawy negatywnie wpływające na relacje z dzieckiem, w które wchodzą osoby pracujące metodą outreach, omówimy poniżej. 


\section{Nauczyciel}

Streetworker, który przybiera postawę nauczyciela może być oceniający i pouczający. Może również próbować stosować w terenie zasady, do których przestrzegania dzieci zobowiązane są w szkole. Przeważnie w celu ochrony dziecka chce on wyznaczać granice zachowania, wskazywać na błędy, które dziecko popełnia. Doświadczenie zawodowe i prywatne podpowiada mu, że pewne zachowania dziecka mogą poprowadzić je w nieodpowiednim kierunku. Dziecko w kontakcie ze streetworkerem wchodzącym w ten zestaw zachowań nie czuje się swobodnie, nie jest w stanie mu zaufać, czuje się kontrolowane. Streetworker może wywyższać się i zaznaczać fakt posiadania większego doświadczenia i wiedzy w porównaniu z dzieckiem. Relacja dziecka z osobą, która wchodzi stale w rolę nauczyciela, nie jest korzystna ani dla dziecka, ani dla samego streetworkera.

\section{Przyjaciel}

W pracy każdego pracownika socjalnego czy innej osoby pomagającej zawodowo ważne jest, aby stawiać wyraźną granicę w relacji z podopiecznym. Zadanie to może być trudne w przypadku pracy z określoną grupą przez dłuższy czas lub z grupą dzieci, jak często bywa w przypadku pracy streetworkera. W rolę przyjaciela streetworker może wejść po wkroczeniu z dzieckiem w relację prywatną. Z powodu szczególnej sympatii między streetworkerem a dzieckiem streetworker przybierający postawę przyjaciela może nie zauważać problemu w negatywnym zachowaniu dziecka, nawet jeśli jest ono skierowane bezpośrednio w jego stronę. Może on również „przymykać oko” na pewne sytuacje, w które jest zamieszane dziecko. W relacji takiej traktuje się dziecko jak równego sobie, jednak zapomina się o podejściu profesjonalnym. Streetworker może stać się powiernikiem najskrytszych tajemnic dziecka i jego rodziny, a przy tym zostać faworytem dziecka. Ucierpieć może na tym relacja streetworkera $\mathrm{z}$ innymi dziećmi, ponieważ kontakt $\mathrm{z}$ faworyzowanym dzieckiem może stać się przedmiotem zazdrości. Przez szczególne przywiązanie dziecka i streetworkera może ucierpieć również relacja innych streetworkerów z faworyzowanym dzieckiem.

\section{Policjant}

Streetworker wchodzący w rolę policjanta czuje na sobie odpowiedzialność za pilnowanie porządku w grupie oraz kontrolowanie, czy w jego najbliższym otoczeniu nie jest łamane prawo lub wewnętrzne zasady grupy. Osoba przybierająca taką postawę chce pokazywać, jakie są konsekwencje nieakceptowanych społecznie zachowań. Problem pojawia się, gdy zamiast skupiać się na budowaniu relacji z dzieckiem, osoba ta swoje działania w grupie ogranicza do permanentnego przestrzegania przed możliwymi 
sankcjami i konsekwencjami. Środowiska zmarginalizowane i „problemowe”, a szczególnie te z obszarów poddanych tak zwanej gettoizacji (Szarfenberg 2010: 6), często cechują się niechęcią, a nawet wrogością do policji i samych policjantów oraz innych służb porządkowych (Machel 2007: 228). Powodem tego jest utarty negatywny obraz policjanta oraz częste występowanie w obszarach marginalizowanych różnego rodzaju problemów społecznych oraz przestępczości. Streetworker przybierający postawę osoby kontrolującej jest kojarzony z policjantem, a złe skojarzenia związane z tym zawodem ściągają na relację z dzieckiem obciążenia. Mogą one pogorszyć lub nawet zrujnować zbudowaną wcześniej relację, a w przypadku początku kontaktu z dzieckiem mogą spowodować zniechęcenie lub nawet agresję ze strony dziecka.

\section{Opiekun}

Osoby pomagające zawodowo są wrażliwe na krzywdę i cierpienie drugiego człowieka. Muszą one radzić sobie z ciągłym oddzielaniem życia prywatnego od zawodowego od problemów tych, którym pomagają na co dzień. Z uwagi na więź, która tworzy się między pracownikiem socjalnym a osobą potrzebującą, oraz wysoką wrażliwość pracownika socjalnego jest to zadanie bardzo trudne, czasem nawet bywa niemożliwe do zrealizowania. Gdy w streetworkerze pracującym z dziećmi będzie mocno dominowała chęć zmiany złego położenia społecznego dziecka i jego rodziny, gdy będzie on chciał za wszelką cenę pomóc wyprostować ścieżki dziecka znajdującego się na złej drodze, może okazać się, że chęć pomocy stanie się czynnikiem wpływającym negatywnie na relację z młodym człowiekiem. Streetworker, chcąc „wybawić” dziecko od problemów, może wejść w rolę rodzica lub opiekuna, który pragnie zapobiec wszelkiemu złu. Przybierając tę postawę, streetworker, mając dobre intencje, może zacząć próbować chronić dziecko przed negatywnym wpływem ze strony otoczenia, doprowadzając nawet do skrajnej sytuacji, w której będzie chciał odbierać mu wolność samostanowienia i decyzji. W codziennej pracy przybieranie takiej postawy może objawiać się permanentnym doradzaniem dotyczącym wyborów mogących w jakiś sposób wpłynąć na późniejszą jakość życia dziecka. W takim przypadku kontakt z dzieckiem może zostać utrudniony lub nawet zerwany, ponieważ - jak już wspomniano - jedną z podstaw w pracy streetworkera jest nieograniczanie wolności osobie potrzebującej.

\section{Bibliografia}

Griffin E. (1994). First Look at Communication Theory - 2nd edition. McGraw-Hill Publishing Company, New York.

Karłyk-Ćwik A. (2014). Autorytet $w$ wychowaniu i resocjalizacji $w$ refleksji przyszłych pedagogów. „Lubelski Rocznik Pedagogiczny”, 1: 43-62. 
Machel H. (2007). Rola i zadania kadry resocjalizacyjnej, w: B. Urban, J. Stanik (red.), Resocjalizacja, t. 2. Wydawnictwo Naukowe PWN, Warszawa: 217-247.

Réseau International des Travailleurs Sociaux de Rue (2008). http://www.travailderue.org/wp-content/uploads/2012/08/guide_FR.pdf (dostęp: 12.02.2020).

Stowarzyszenie „PoMoc” dla Kobiet i Dzieci im. Marii Niepokalanej (2010). Przewodnik Streetworkera. Zakład Poligraficzny SINDRUK, Katowice-Opole.

StreetInvest (2013, Sierpień). StreetInvest - Effective Principles of Street Work; http://www. streetinvest.org/control/uploads/files/1375266589 _ STREETINVEST_10_EFFECTIVE_PRINCIPLES_OF_STREET_WORK.pdf (dostęp: 17.02.2020).

Szarfenberg R. (2010, Maj 4). Marginalizacja $i$ wykluczenie społeczne - panorama językowo-teoretyczna. Instytut Polityki Społecznej UW; http://rszarf.ips.uw.edu.pl/pdf/miws_panorama.pdf (dostęp: 23.01.2020).

Young E.L., Hoffmann L.L. (2004). National Association of School Psychologists; http://janenotplain.com/wp-content/uploads/2015/08/self-esteem-in-children_strategies_school-psychol. pdf (dostęp: 25.01.2020). 